IZA DP No. 5950

Integrating Personality Psychology into Economics

James Heckman

August 2011

Forschungsinstitut zur Zukunft der Arbeit Institute for the Study of Labor 


\title{
Integrating Personality Psychology into Economics
}

\author{
James Heckman \\ University of Chicago, American Bar Foundation, \\ University College Dublin and IZA
}

Discussion Paper No. 5950

August 2011

IZA

P.O. Box 7240

53072 Bonn

Germany

Phone: +49-228-3894-0

Fax: +49-228-3894-180

E-mail: iza@iza.org

Any opinions expressed here are those of the author(s) and not those of IZA. Research published in this series may include views on policy, but the institute itself takes no institutional policy positions.

The Institute for the Study of Labor (IZA) in Bonn is a local and virtual international research center and a place of communication between science, politics and business. IZA is an independent nonprofit organization supported by Deutsche Post Foundation. The center is associated with the University of Bonn and offers a stimulating research environment through its international network, workshops and conferences, data service, project support, research visits and doctoral program. IZA engages in (i) original and internationally competitive research in all fields of labor economics, (ii) development of policy concepts, and (iii) dissemination of research results and concepts to the interested public.

IZA Discussion Papers often represent preliminary work and are circulated to encourage discussion. Citation of such a paper should account for its provisional character. A revised version may be available directly from the author. 
IZA Discussion Paper No. 5950

August 2011

\section{ABSTRACT}

\section{Integrating Personality Psychology into Economics ${ }^{*}$}

This paper reviews the problems and potential benefits of integrating personality psychology into economics. Economists have much to learn from and contribute to personality psychology.

JEL Classification: $\quad$ I2, J24

Keywords: personality psychology, behavioral economics, identification, causality

Corresponding author:

James Heckman

The University of Chicago

Department of Economics

1126 E. 59th St.

Chicago, IL 60637

United States

E-mail: jjh@uchicago.edu

\footnotetext{
* Presented at Korea Development Institute, Tuesday, August 9, 2011.

This research was supported by grants from NIH R01-HD054702, R01-HD065072, and K01AG033182; the University of Chicago; The Institute for New Economic Thinking (INET); A New Science of Virtues: A Project of the University of Chicago; the American Bar Foundation; a conference series from the Spencer Foundation; the JB \& MK Pritzker Family Foundation; the Buffett Early Childhood Fund; the Geary Institute, University College Dublin, Ireland; and an anonymous funder. This paper draws on Almlund et al. (2011). I thank Angela Duckworth and Tim Kautz for helpful comments.
} 
What can economists learn from and contribute to personality psychology? What do we learn from personality psychology? Personality traits predict many behaviors - sometimes with the same or greater strength as conventional cognitive traits. Personality psychology considers a wider array of actions than are usually considered by economists and enlarges the economist's way to describe and model the world. Personality traits are not set in stone. They change over the life cycle. They are a possible avenue for policy intervention.

Personality psychologists lack precise models. Economics provides a clear framework for recasting the field. Economics now plays an important role in clarifying the concepts and empirical content of psychology. More precise models reveal basic identification problems that plague measurement in psychology. At an empirical level, "cognitive" and "noncognitive" traits are not easily separated.

Moreover, personality psychologists typically present correlations and not causal relationships. Many contemporaneously measured relationships suffer from the problem of reverse causality. Economists can apply their tools to define and estimate causal mechanisms. In addition, psychological measures have substantial measurement error. Econometric tools account for measurement error, and doing so makes a difference. Economists formulate and estimate mechanisms of investment - how traits can be changed for the better.

There are major challenges in integrating personality psychology and economics. Economists need to link the traits of psychology with the preferences, constraints and expectation mechanisms of economics. We need to develop rigorous methods for analyzing causal relationships in both fields. We also need to develop a common language and a common framework to promote interdisciplinary exchange.

There is a danger in assuming that basic questions of content and identification have been answered by psychologists at the level required for rigorous economic analysis. In explaining outcomes, how important is the person? How important is the situation? How important is their interaction? I address these issues in this paper.

\subsection{A Brief History of Personality Psychology}

Alfred Binet, architect of the first modern intelligence test that became the Stanford-Binet IQ test, noted that performance in school

"...admits of other things than intelligence; to succeed in his studies, one must have qualities which depend on attention, will, and character; for example a certain docility, a regularity of habits, and especially continuity of effort. A child, even if intelligent, will learn little in class if he never listens, if he spends his time in playing tricks, in giggling, is playing truant."

-Binet (1916, p. 254) 
All later pioneers have made similar statements. Many feature the Big Five trait "Conscientiousness" as a main determinant of success. ${ }^{1}$ Before considering the Big Five traits, it is useful to briefly examine the modern concept of cognition by way of contrast.

\subsection{Cognition: "g" - a single factor that is claimed to represent intelligence}

Traditional "g" is a product of early Twentieth Century psychology. The concept of "g" has been broadened even beyond the traditional subcomponents of "fluid" and "crystallized" intelligence. Figure 1 summarizes current thinking where "g" or general intelligence is at the top of a large pyramid of cognitive traits.

\section{Figure 1: An Hierarchical Scheme of General Intelligence and Its Components}

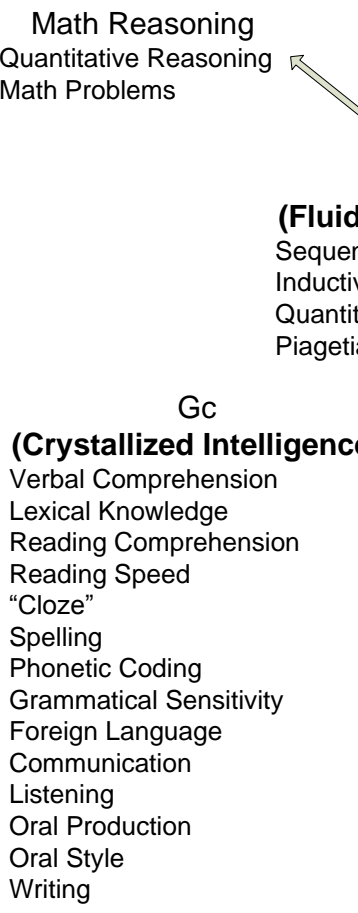

Visual Perception

Visualization

Spatial Relations

Closure Speed

Closure Flexibility

Serial Perceptual Integration

Gf

(Fluid Intelligence)

Sequential Reasoning

titative Reasoning

Spatial Scanning

Imagery

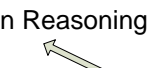

ing

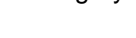

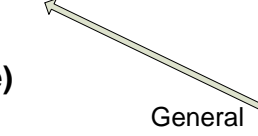

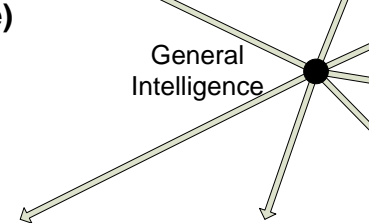

Ideational Fluency

Ideational Fluency

Naming Facility

Expressional Fluency

Word Fluency

Creativity

Figural Fluency

Figural Flexibility
Closure

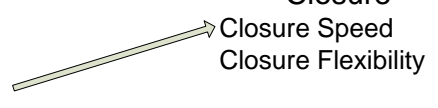

Perceptual Speed

Number Computation

RT and other Elementary Cognitive Tasks

Stroop

Clerical Speed

Digit/Symbol

Learning and Memory Memory Span

Associative Memory

Free Recall Memory

Meaningful Memory

Visual Memory

Knowledge and Achievement

General School Achievement

$\checkmark$ Verbal Information and Knowledge

Information and Knowledge, Math and Science

Technical and Mechanical Knowledge

Knowledge of Behavioral Content

Source: Recreated from Ackerman and Heggestad (1997), based on Carroll (1993).

\footnotetext{
${ }^{1}$ See Almlund et al. (2011).
} 


\subsection{Personality Traits}

Early pioneers used a lexical approach to define personality. They classified words that are used to describe people. This practice culminated in the "Big Five" derived from factor analysis of measurements of personality extracted from a variety of measures - observer reports, tests and measured productivity on the job (Costa and McCrae, 1992, Goldberg, 1993). No single " $\mathrm{g}_{p}$ " explains all traits. There are strong correlations within clusters but weak correlations across clusters.

\section{Table 1: The Big Five Domains and Their Facets}

\begin{tabular}{|c|c|c|c|c|}
\hline $\begin{array}{c}\text { Big Five Personality } \\
\text { Factor }\end{array}$ & $\begin{array}{c}\text { American Psychology } \\
\text { Association Dictionary } \\
\text { description }\end{array}$ & $\begin{array}{l}\text { Facets (and correlated } \\
\text { trait adjective) }\end{array}$ & Related Traits & $\begin{array}{l}\text { Childhood } \\
\text { Temperament Traits }\end{array}$ \\
\hline Conscientiousness & $\begin{array}{l}\text { "the tendency to be } \\
\text { organized, responsible, } \\
\text { and hardworking" }\end{array}$ & $\begin{array}{l}\text { Competence (efficient) } \\
\text { Order (organized) } \\
\text { Dutifulness (not careless) } \\
\text { Achievement striving } \\
\text { (ambitious) } \\
\text { Self-discipline (not lazy) } \\
\text { Deliberation (not } \\
\text { impulsive) }\end{array}$ & $\begin{array}{l}\text { Grit } \\
\text { Perseverance } \\
\text { Delay of gratification } \\
\text { Impulse control } \\
\text { Achievement striving } \\
\text { Ambition } \\
\text { Work ethic }\end{array}$ & $\begin{array}{l}\text { Attention/(lack of) } \\
\text { distractibility } \\
\text { Effortful control } \\
\text { Impulse control/delay } \\
\text { of gratification } \\
\text { Persistence } \\
\text { Activity }\end{array}$ \\
\hline $\begin{array}{l}\text { Openness to } \\
\text { Experience }\end{array}$ & $\begin{array}{l}\text { "the tendency to be open } \\
\text { to new aesthetic, } \\
\text { cultural, or intellectual } \\
\text { experiences" }\end{array}$ & $\begin{array}{l}\text { Fantasy (imaginative) } \\
\text { Aesthetic (artistic) } \\
\text { Feelings (excitable) } \\
\text { Actions (wide interests) } \\
\text { Ideas (curious) } \\
\text { Values (unconventional) }\end{array}$ & - & $\begin{array}{l}\text { Sensory sensitivity } \\
\text { Pleasure in low- } \\
\text { intensity activities } \\
\text { Curiosity }\end{array}$ \\
\hline Extraversion & $\begin{array}{l}\text { "an orientation of one's } \\
\text { interests and energies } \\
\text { toward the outer world } \\
\text { of people and things } \\
\text { rather than the inner } \\
\text { world of subjective } \\
\text { experience; } \\
\text { characterized by } \\
\text { positive affect and } \\
\text { sociability" }\end{array}$ & $\begin{array}{l}\text { Warmth (friendly) } \\
\text { Gregariousness } \\
\text { (sociable) } \\
\text { Assertiveness (self- } \\
\text { confident) } \\
\text { Activity (energetic) } \\
\text { Excitement seeking } \\
\text { (adventurous) } \\
\text { Positive emotions } \\
\text { (enthusiastic) }\end{array}$ & - & $\begin{array}{l}\text { Surgency } \\
\text { Social dominance } \\
\text { Social vitality } \\
\text { Sensation seeking } \\
\text { Shyness" } \\
\text { Activity } \\
\text { Positive emotionality } \\
\text { Sociability/affiliation }\end{array}$ \\
\hline Agreeableness & $\begin{array}{l}\text { "the tendency to act in a } \\
\text { cooperative, unselfish } \\
\text { manner" }\end{array}$ & $\begin{array}{l}\text { Trust (forgiving) } \\
\text { Straight-forwardness (not } \\
\text { demanding) } \\
\text { Altruism (warm) } \\
\text { Compliance (not } \\
\text { stubborn) } \\
\text { Modesty (not show-off) } \\
\text { Tender-mindedness } \\
\text { (sympathetic) }\end{array}$ & $\begin{array}{l}\text { Empathy } \\
\text { Perspective taking } \\
\text { Cooperation } \\
\text { Competitiveness }\end{array}$ & $\begin{array}{l}\text { Irritability }{ }^{*} \\
\text { Aggressiveness } \\
\text { Willfulness }\end{array}$ \\
\hline $\begin{array}{l}\text { Neuroticism/ } \\
\text { Emotional Stability }\end{array}$ & $\begin{array}{l}\text { Emotional stability is } \\
\text { "predictability and } \\
\text { consistency in emotional } \\
\text { reactions, with absence } \\
\text { of rapid mood changes." } \\
\text { Neuroticism is "a } \\
\text { chronic level of } \\
\text { emotional instability and } \\
\text { proneness to } \\
\text { psychological distress." }\end{array}$ & $\begin{array}{l}\text { Anxiety (worrying) } \\
\text { Hostility (irritable) } \\
\text { Depression (not } \\
\text { contented) } \\
\text { Self-consciousness (shy) } \\
\text { Impulsiveness (moody) } \\
\text { Vulnerability to stress } \\
\text { (not self-confident) }\end{array}$ & $\begin{array}{l}\text { Internal vs. External } \\
\text { Locus of control } \\
\text { Core self-evaluation } \\
\text { Self-esteem } \\
\text { Self-efficacy } \\
\text { Optimism } \\
\text { Axis I } \\
\text { psychopathologies } \\
\text { (mental disorders) } \\
\text { including depression } \\
\text { and anxiety disorders }\end{array}$ & $\begin{array}{l}\text { Fearfulness/behavioral } \\
\text { inhibition } \\
\text { Shyness }^{*} \\
\text { Irritability } \\
\text { Frustration } \\
\text { (Lack of) soothability } \\
\text { Sadness }\end{array}$ \\
\hline
\end{tabular}

Notes: Facets specified by the NEO-PI-R personality inventory (Costa and McCrae 1992). Trait adjectives in parentheses from the Adjective Check List (Gough and Heilbrun 1983). ${ }^{*}$ These temperament traits may be related to two Big Five factors. Source: Table adapted from John and Srivastava (1999). 
The Big Five predict many outcomes. The Big Five are defined without reference to any context (i.e., situation). This practice gives rise to an identification problem that I discuss below.

\subsection{The Person-Situation Debate: A Strong Influence on Behavioral Economics}

Is variation across people in behavior a consequence of personal traits or of situations? Economists are still badly divided over this question. The modern origins of the debate start with the works of psychologist Walter Mischel:

"... with the possible exception of intelligence, highly generalized behavioral consistencies have not been demonstrated, and the concept of personality traits as broad dispositions is thus untenable"

-Mischel (1968, p. 146)

Many behavioral economists hold a similar view and appeal to Mischel as a guiding influence.

"The great contribution to psychology by Walter Mischel [...] is to show that there is no such thing as a stable personality trait."

-Thaler (2008)

The accumulated evidence speaks strongly against the claims of Mischel and the behavioral economists. ${ }^{2}$

\subsection{Personality Psychology After the Person-Situation Debate}

Correlational evidence shows that for many outcomes, measured personality traits are as predictive, and are sometimes more predictive, than standard measures of cognition. Traits are stable across situations. Situations also matter. Behavioral genetics show that personality traits are as heritable as cognitive traits. Alterations in brain structure and function through accidents, disease and by experiments affect measured personality. ${ }^{3}$

\footnotetext{
${ }^{2}$ See Almlund et al. (2011).

${ }^{3}$ See Almlund et al. (2011).
} 


\subsection{The Predictive Power of Personality Traits}

A growing body of evidence suggests that personality measures-especially those related to Conscientiousness, and, to a lesser extent, Neuroticism-predict a wide range of outcomes. The predictive power of any particular personality measure tends to be less than the predictive power of IQ but in some cases rivals or exceeds it.

\subsection{Difficulties in Synthesizing Studies of the Effects of Personality}

Measures of personality and cognition differ among studies. Different studies use different measures of predictive power. Many studies do not address the question of causality, i.e., does the measured trait cause (rather than just predict) the outcome?

Few economists or psychologists working on the relationship between personality and outcomes address the issue of causality, and when they do so, it is usually by employing early measures of cognition and personality to predict later outcomes This practice trades an endogeneity problem with an errors in variables problem. Almlund et al. (2011) discuss alternative approaches to causality building on the analysis of Hansen et al. (2004).

\subsection{Main Findings from Predictive Analyses}

The predictive power of "g" decreases with the level of job complexity. Personality traits are predictive at all levels of job complexity. Conscientiousness is the most predictive Big Five trait across many outcomes such as educational attainment, grades, job performance across a range of occupational categories, longevity and criminality. Neuroticism (and related Locus of Control) predicts schooling outcomes and labor market search. Other traits play roles at finer levels. I now present examples of the power of personality traits.

\subsection{Educational Attainment and Achievement}

In explaining educational attainment, Conscientiousness plays a powerful role. See Figure 2 


\section{Figure 2: Association of the Big Five and Intelligence with Years of Schooling in GSOEP}

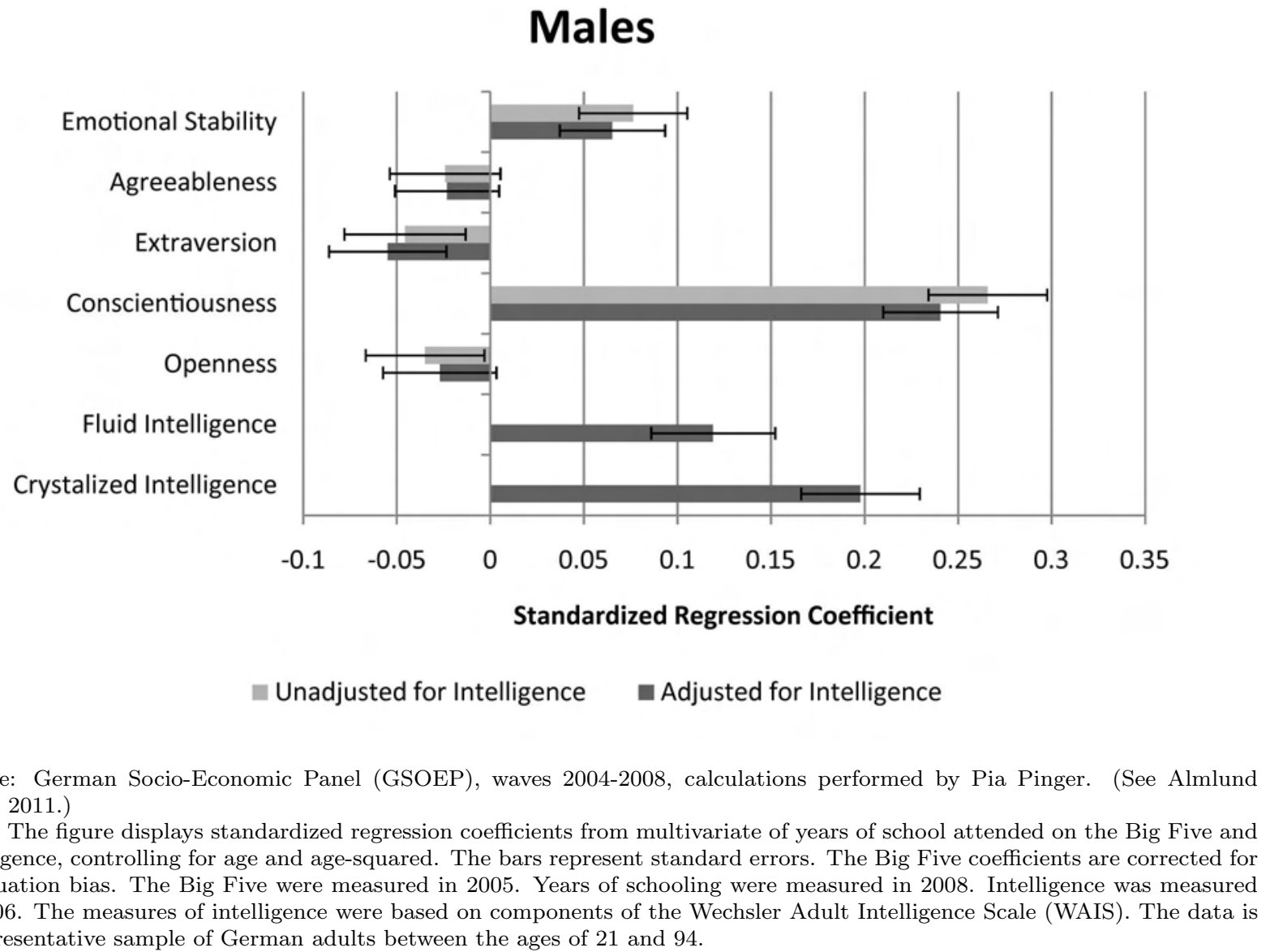

Another example is the GED in America. GEDs are high school dropouts who exam certify to be high school equivalents. They have the same cognitive skills as high school graduates but much lower noncognitive skills. See Figures 3 and 4 . 
Figure 3: Distribution of Cognitive and Non-Cognitive Skills by Education Group

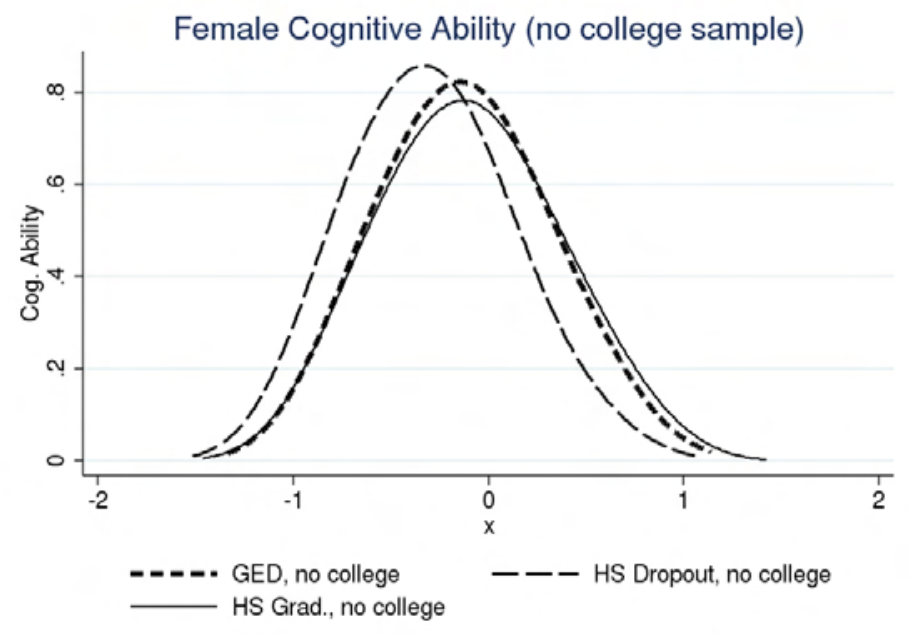

Source: Heckman et al. (2011).

Figure 4: Distribution of Cognitive and Non-Cognitive Skills by Education Group

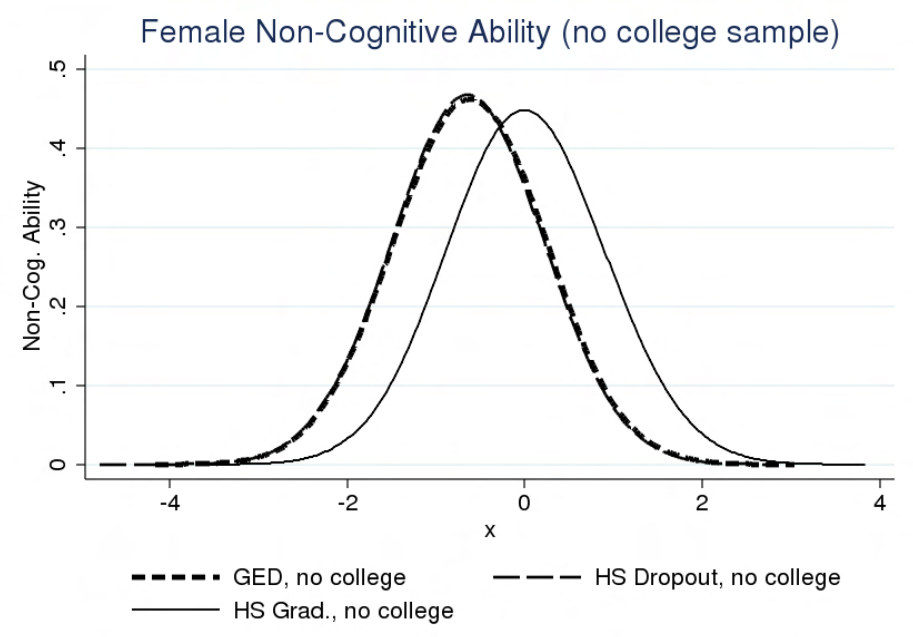

Source: Heckman et al. (2011). 
GEDs earn at the rate of dropouts. Their lower levels of noncognitive skill leads to lower wages than ordinary high school graduates even though they have the same level of cognitive skills.

Cognitive and noncognitive skills are both important in explaining college graduation. See Figures 5 and 6. Persons with low levels of noncognitive skills are unlikely to graduate college, as are persons with low levels of cognitive skills.

Figure 5: Probability of Being a 4-year-college Graduate or Higher at Age 30, Males

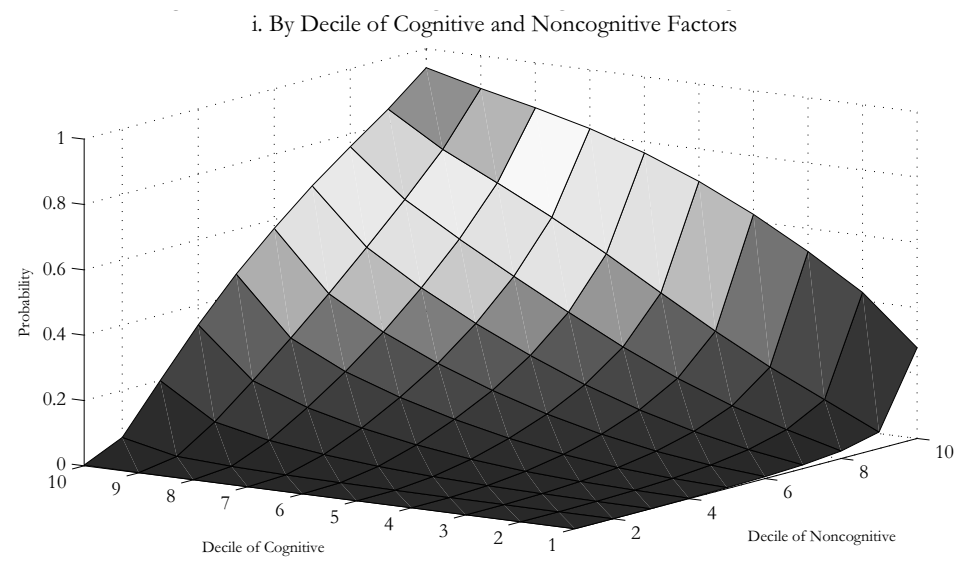

Notes: The data are simulated from the estimates of the model and the NLSY79 sample. Higher deciles are associated with higher values of the variable. The confidence intervals are computed using bootstrapping (200 draws). Solid lines depict probability, and dashed lines, $2.5 \%-97.5 \%$ confidence intervals. The upper curve is the joint density. The two marginal curves (ii) and (iii) are evaluated at the mean of the trait not being varied.

Source: Heckman et al. (2006, Figure 21). 


\section{Figure 6: Probability of Being a 4-year-college Graduate or Higher at Age}

30, Males
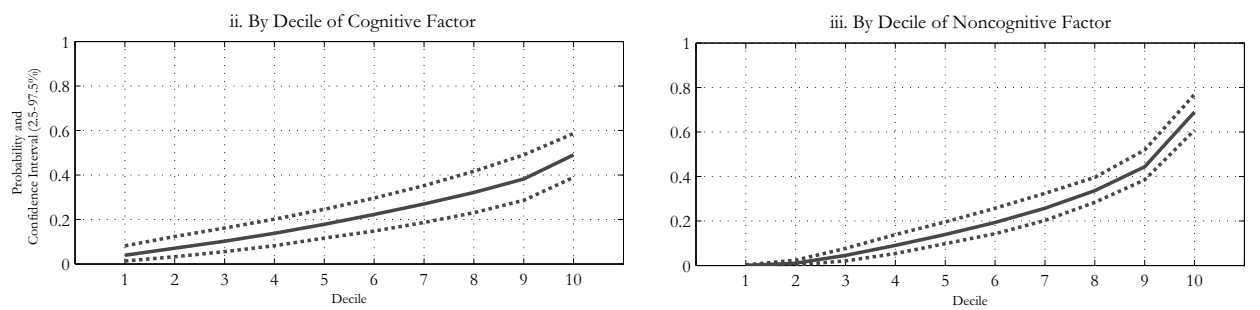

Notes: The data are simulated from the estimates of the model and the NLSY79 sample. Higher deciles are associated with higher values of the variable. The confidence intervals are computed using bootstrapping (200 draws). Solid lines depict probability, and dashed lines, $2.5 \%-97.5 \%$ confidence intervals. The upper curve is the joint density. The two marginal curves (ii) and (iii) are evaluated at the mean of the trait not being varied.

Source: Heckman et al. (2006. Figure 21).

Similar results hold for course grades. See Figure 7 Indeed, course grades are a good measure of conscientiousness. (See Almlund et al., 2011, Borghans et al., 2011,)

\section{Figure 7: Correlations of the Big Five and Intelligence with Course Grades}

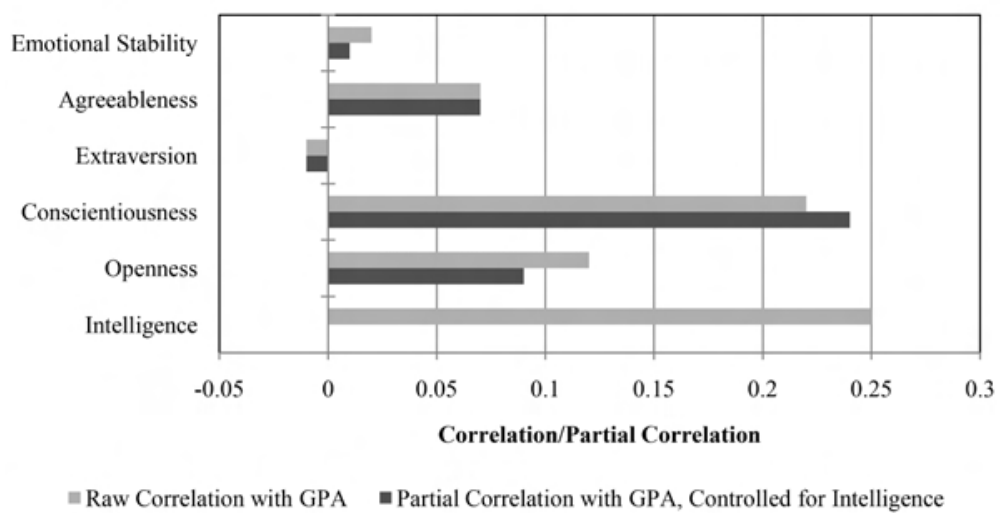

Notes: All correlations are significant at the $1 \%$ level. The correlations are corrected for scale reliability and come from a meta analysis representing a collection of studies representing samples of between $\mathrm{N}=31,955$ to $\mathrm{N}=70,926$, depending on the trait. The meta-analysis did not clearly specify when personality was measured relative to course grades. Source: Poropat (2009).

\subsection{Labor Market Outcomes}

Intelligence is the greatest single predictor of job performance, especially in complex tasks, but noncognitive skills are also important predictors. See Figure 8 


\section{Figure 8: Associations with Job Performance}

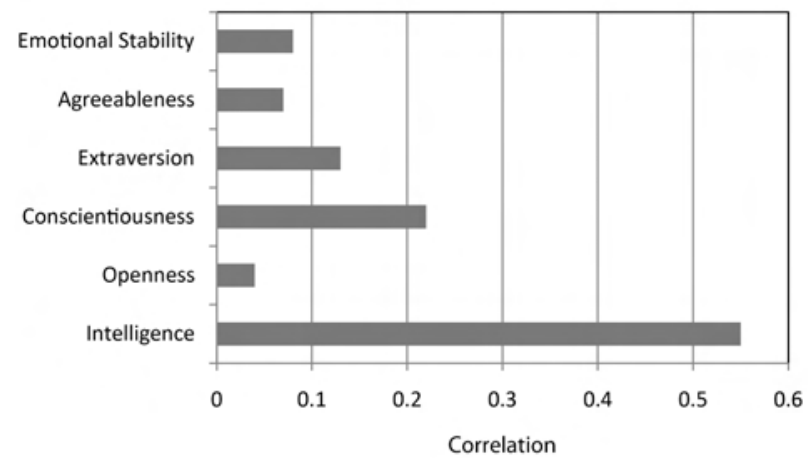

Notes: The values for personality are correlations that were corrected for sampling error, censoring, and measurement error. Job performance was based on performance ratings, productivity data and training proficiency. The authors do report the timing of the measurements of personality relative to job performance. Of the Big Five, the coefficient on Conscientiousness is the only one that is statistically significant with a lower bound on the 90credibility value of 0.10 . The value for IQ is a raw correlation.

Sources: The correlations reported for personality traits come from a meta-analysis conducted by Barrick and Mount (1991). The correlation reported for IQ and job performance come from Schmidt and Hunter (2004).

\subsection{Longevity}

Personality traits also predict longevity. In particular, Conscientiousness is a better predictor than IQ. See Figure 9

\section{Figure 9: Correlations of Mortality with Personality, IQ, and Socioeconomic}

\section{Status (SES)}

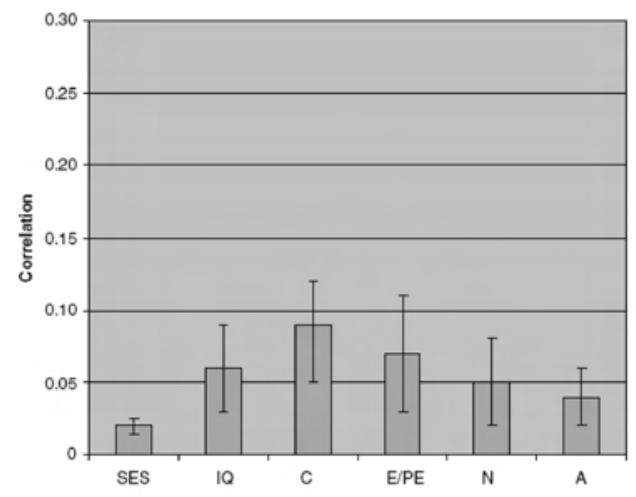

Notes: The figure represents results from a meta-analysis of 34 studies. Average effects (in the correlation metric) of low socioeconomic status (SES), low IQ, low Conscientiousness (C), low Extraversion/Positive Emotion (E/PE), Neuroticism (N), and low Agreeableness (A) on mortality. Error bars represent standard error. The lengths of the studies represented vary from 1 year to 71 years.

Source: Roberts et al. (2007) 


\subsection{Conceptualizing Personality Within an Economic Model}

How should one conceptualize these correlations and establish a causal basis for them? Recent work (Almlund et al. 2011) develops economic models of personality and their implications for measurement of personality and preference. They place the concept of personality within an economic framework. Personality is defined as an emergent property of a system. Economic models frame and solve a central identification problem in empirical psychology: How to go from measurements of personality to personality traits.

It is important to distinguish personality traits from measured personality. One definition of personality by a leading psychologist is:

"Personality traits are the relatively enduring patterns of thoughts, feelings, and behaviors that reflect the tendency to respond in certain ways under certain circumstances."

-Roberts (2009, p. 140)

His conceptual framework for personality is presented in Figure 10. Personality is a property of a system. This type of analysis is typical of the models used in personality psychology.

Figure 10: Roberts's Model of Personality

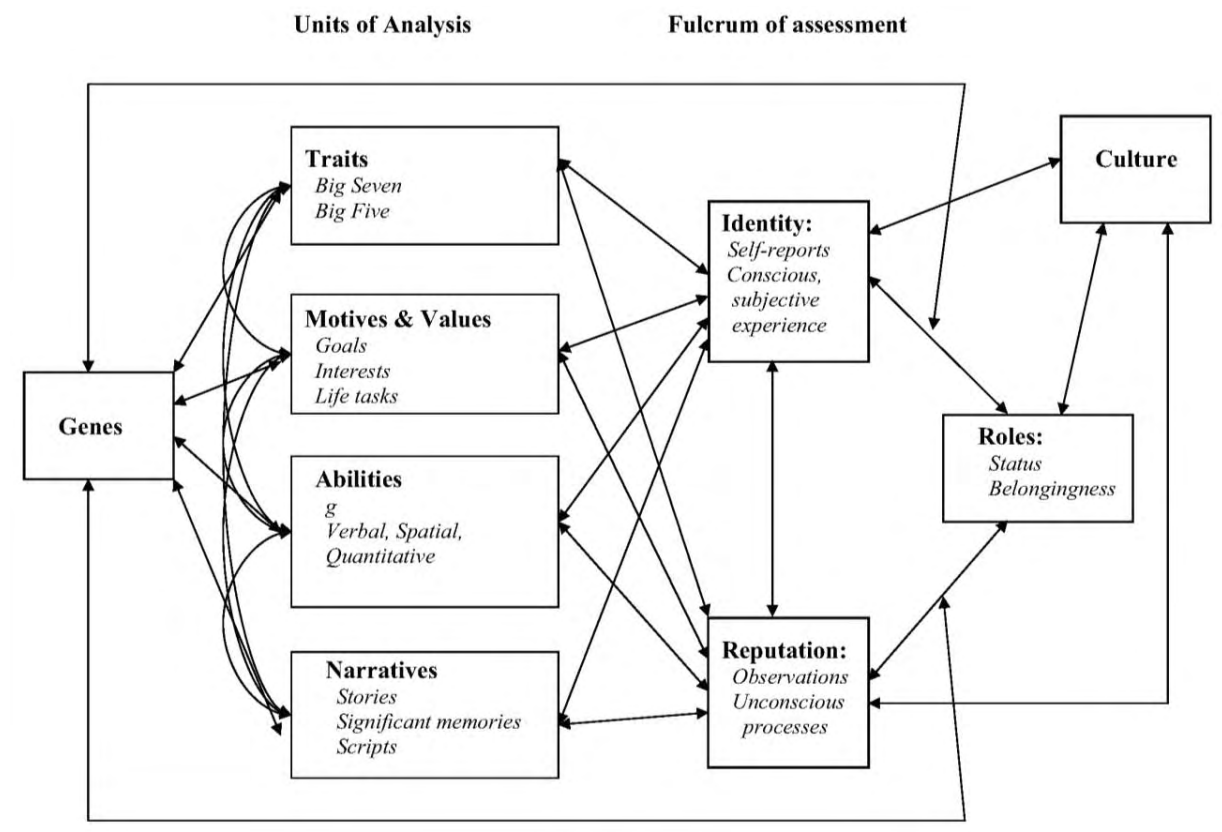

Source: Roberts (2006). 


\subsection{An Economic Framework for Conceptualizing and Measuring Personality and Personality Traits}

How can we interpret personality within economic models? Through preferences (the standard approach), constraints (Borghans et al., 2008) or through expectations? Or does it operate through all three?

\subsection{Personality Affects Productivity}

Almlund et al. (2011) develop models in which productivity in task $j$ depends on the traits of agents represented by trait vector $\theta$, and the "effort" they expend on the task, $e_{j}$ :

$$
P_{j}=\phi_{j}\left(\theta, e_{j}\right), \quad j \in \mathcal{J}=\{1, \ldots, J\}, e_{j} \in \mathcal{E}, \theta \in \Theta .
$$

Traits $\theta$ are endowments, like a public good. $\sum_{j=1}^{J} e_{j}=\bar{e} . \bar{e}$ is endowment.

$\phi_{j}\left(\theta, e_{j}\right)$ is concave and increasing in $e_{j} ; \frac{\partial^{2} \phi_{j}}{\partial \theta \partial e_{j}^{\prime}} \geq 0, \forall j . R_{j}$ is the reward per unit task output. The agent is assumed to maximize

$$
\sum_{j=1}^{J} R_{j} \phi_{j}\left(\theta, e_{j}\right)
$$

with respect to $\left\{e_{j}\right\}_{j=1}^{J}$ subject to the constraint $\sum_{j=1}^{J} e_{j}=\bar{e}$. In general, as $R_{j} \uparrow e_{j} \uparrow$. Effort in one task might diminish effort in another. If tasks are mutually exclusive, we obtain the Roy model (Heckman and Honoré, 1990, Heckman and Sedlacek, 1985).

\subsection{Identifying Personality Traits From Measured Performance on Tasks}

I next consider a basic identification problem. Some tasks may require only a single trait or only a subset of all of the traits. Divide $\theta$ into "mental" $(\mu)$ and "personality" $(\pi)$ traits, $\theta_{\mu}$ and $\theta_{\pi}$. To use performance on a task (or on multiple measures of the task) to identify a trait requires that performance on certain tasks (performance on a test, performance in an interpersonal situation, etc.) depends exclusively on one component of $\theta$, say $\theta_{1, j}$, as well as on the effort used in the task. Thus measurement assumes task $j$ output 
is generated by the following relationship:

$$
P_{j}=\phi_{j}(\underbrace{\theta_{1, j}}_{\begin{array}{c}
\text { single } \\
\text { trait } \\
\text { used in } \\
\text { trait } j
\end{array}}, e_{j}) .
$$

We need to standardize for effort at a benchmark level, say $e^{*}$, to use $P_{j}$ to identify a measure of the trait $\theta_{1, j}$.

The activity of picking a task (or a collection of tasks) that measure a particular trait $\left(\theta_{1, j}\right.$ in our example) is called operationalization in psychology. Demonstrating that a measure successfully operationalizes a trait is called construct validity. Note, however, that we need to standardize for effort to measure the trait. Otherwise variation in effort produces variation in the measured trait across situations with different incentives.

\subsection{A Fundamental Identification Problem}

Operationalization and construct validation require heroic assumptions. Even if one adjusts for effort in a task, measured productivity may depend on multiple traits. Thus two components of $\theta$ (say $\theta_{1, \mu}, \theta_{1, \pi}$ ) may determine productivity in $j$. Without further information, one cannot infer which of the two traits produces the productivity in $j$. In general, even having two (or more) measures of productivity that depend on $\left(\theta_{1, \mu}, \theta_{1, \pi}\right)$ is not enough to identify the separate components.

Consider the following case of two productivity measures for the two tasks $j$ and $j^{\prime}$ :

$$
\begin{aligned}
P_{j} & =\phi_{j}\left(\theta_{1, \mu}, \theta_{1, \pi}, e_{j}\right) \\
P_{j^{\prime}} & =\phi_{j^{\prime}}\left(\theta_{1, \mu}, \theta_{1, \pi}, e_{j^{\prime}}\right), \quad j \neq j^{\prime} .
\end{aligned}
$$

Standardize measurements at a common level of effort $e_{j}=e_{j^{\prime}}=e^{*}$. Note that if the supports of $e_{j}$ and $e_{j^{\prime}}$ are disjoint, no $\left(\theta_{1, \mu}, \theta_{1, \pi}\right)$ exists. Assume that the $\phi_{k}()$ are known. If the system of equations satisfies a local rank condition, then one can solve for the pair $\left(\theta_{1, \mu}, \theta_{1, \pi}\right)$ at $e^{*}$. Only the pair is identified. One cannot (without further information) determine which component of the pair is $\theta_{1, \mu}$ or $\theta_{1, \pi}$.

In the absence of dedicated constructs (constructs that are generated by only one component of $\theta$ ), there is an intrinsic identification problem that arises in using measures of productivity in tasks to infer traits. Analysts have to make one normalization in order to identify the traits. However, we need only one such construct joined with patterned structures on how $\theta$ enters other task to identify the vector $\theta$ (e.g. one 
example is a recursive, triangular structure). See the discussion in Almlund et al. (2011).

\subsection{Examples of Nonidentification}

IQ and achievement test scores reflect incentives and efforts, and capture both cognitive and personality traits. Table 2 summarizes the evidence that paying disadvantaged students for correct answers on IQ tests substantially raises measured IQ. Almlund et al. (2011) summarize many other studies.

Table 2: Incentives and Performance on Intelligence Tests

\begin{tabular}{|c|c|c|c|c|}
\hline Study & $\begin{array}{c}\text { Sample and Study } \\
\text { Design }\end{array}$ & $\begin{array}{l}\text { Experimental } \\
\text { Group }\end{array}$ & $\begin{array}{c}\text { Effect size of incentive } \\
\text { (in standard } \\
\text { deviations) }\end{array}$ & Summary \\
\hline $\begin{array}{l}\text { Edlund } \\
\text { [1972] }\end{array}$ & $\begin{array}{l}\text { Between subjects } \\
\text { study. } 11 \text { matched } \\
\text { pairs of low SES } \\
\text { children; children } \\
\text { were about one } \\
\text { standard deviation } \\
\text { below average in } \\
\text { IQ at baseline }\end{array}$ & $\begin{array}{l}\text { M\&M candies } \\
\text { given for each } \\
\text { right answer }\end{array}$ & $\begin{array}{l}\text { Experimental group } \\
\text { scored } 12 \text { points higher } \\
\text { than control group } \\
\text { during a second testing } \\
\text { on an alternative form of } \\
\text { the Stanford Binet } \\
\text { (about } 0.8 \text { standard } \\
\text { deviations) }\end{array}$ & $\begin{array}{l}\text { “...a carefully chosen } \\
\text { consequence, candy, given } \\
\text { contingent on each occurrence } \\
\text { of correct responses to an IQ } \\
\text { test, can result in a } \\
\text { significantly higher IQ } \\
\text { score.”(p. 319) }\end{array}$ \\
\hline $\begin{array}{l}\text { Breuning } \\
\text { and Zella } \\
{[1978]}\end{array}$ & $\begin{array}{l}\text { Within and } \\
\text { between subjects } \\
\text { study of } 485 \\
\text { special education } \\
\text { high school } \\
\text { students all took IQ } \\
\text { tests, then were } \\
\text { randomly assigned } \\
\text { to control or } \\
\text { incentive groups to } \\
\text { retake tests. } \\
\text { Subjects were } \\
\text { below-average in } \\
\text { IQ. }\end{array}$ & $\begin{array}{l}\text { Incentives such as } \\
\text { record albums, } \\
\text { radios }(<\$ 25) \text { given } \\
\text { for improvement in } \\
\text { test performance }\end{array}$ & $\begin{array}{l}\text { Scores increased by } \\
\text { about } 17 \text { points. Results } \\
\text { were consistent across } \\
\text { the Otis-Lennon, WISC- } \\
\text { R, and Lorge-Thorndike } \\
\text { tests. }\end{array}$ & $\begin{array}{l}\text { "In summary, the promise of } \\
\text { individualized incentives } \\
\text { contingent on an increase in } \\
\text { IQ test performance (as } \\
\text { compared with pretest } \\
\text { performance) resulted in an } \\
\text { approximate } 17 \text {-point } \\
\text { increase in IQ test scores. } \\
\text { These increases were equally } \\
\text { spread across subtests... The } \\
\text { incentive condition effects } \\
\text { were much less pronounced } \\
\text { for students having pretest } \\
\text { IQs between } 98 \text { and } 120 \text { and } \\
\text { did not occur for students } \\
\text { having pretest IQs between } \\
121 \text { and } 140 . \text { (p. } 225 \text { ) }\end{array}$ \\
\hline
\end{tabular}

A considerable fraction of the variance in achievement tests is explained by personality traits. See Figure 11. Grades are explained more by the Big Five traits than by IQ. See Figure 12. 
Figure 11: AFQT Score Decomposed by IQ, Rosenberg, and Rotter

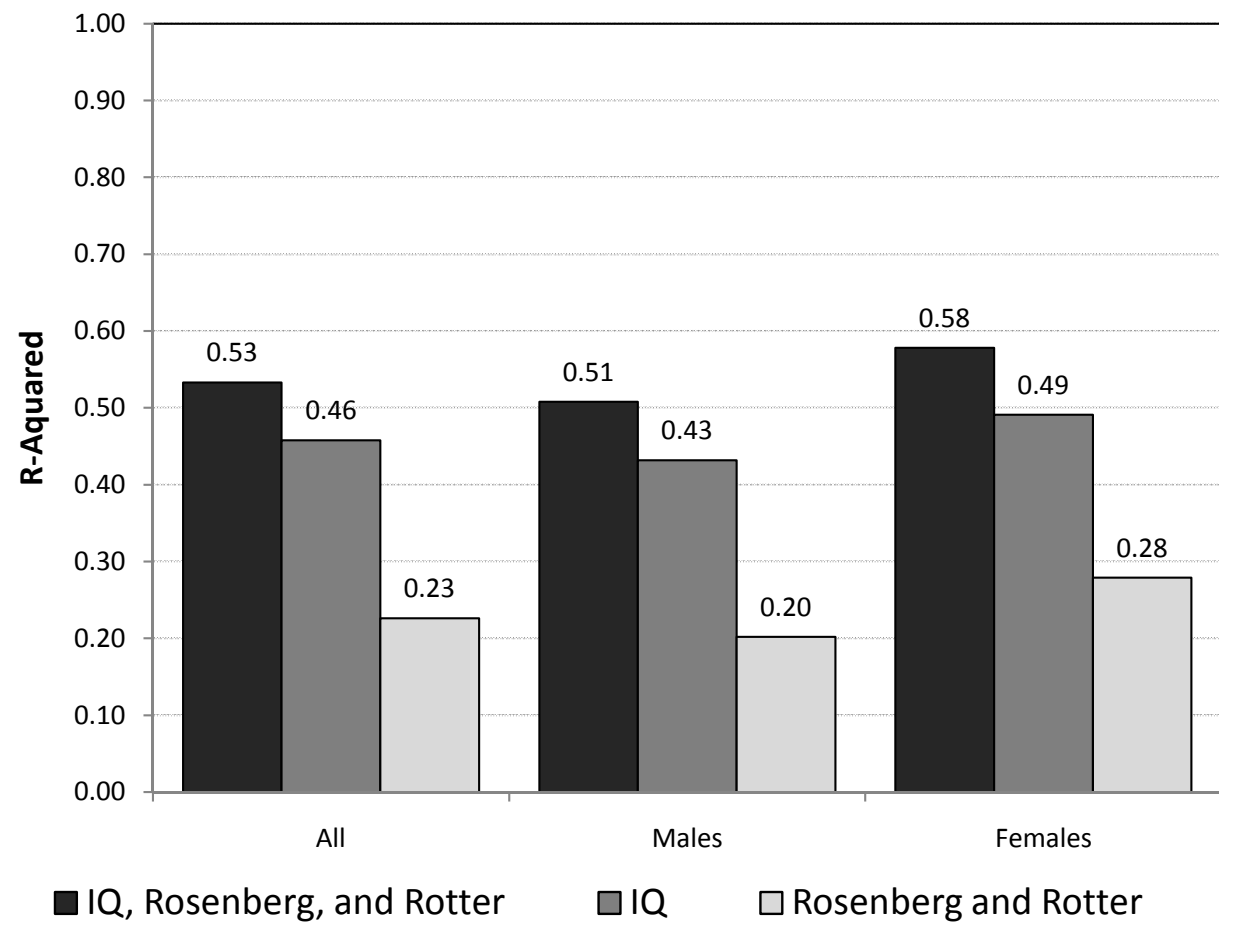

Notes: The data come from the NLSY. Rosenberg, and Rotter were administered in 1979. The ASVAB was administered in 1980.To account for varying levels of schooling at the time of the test, scores have been adjusted for schooling at the time of the test conditional on final schooling using the method developed in Hansen et al. (2004). AFQT is constructed from the Arithmetic Reasoning, Word Knowledge, Numeric Operations, and Paragraph Comprehension ASVAB subtests. DAT and DAT percentile, IQ, and GPA are from high school transcript data. IQ is pooled across several IQ tests using IQ percentiles. GPA is the individual's core-subject GPA from each year of school. Sample excludes the military over-sample. Background variables include mother's highest grade completed, father's highest grade completed, southern residence at age 14, urban residence at age 14, living in a broken home at age 14, receiving newspapers in the household at age 14, receiving magazines in the household at age 14, and the household having a library card at age 14 .

Source: Borghans et al. (2011). 


\section{Figure 12: DAT scores and GPA decomposed by IQ and Personality}

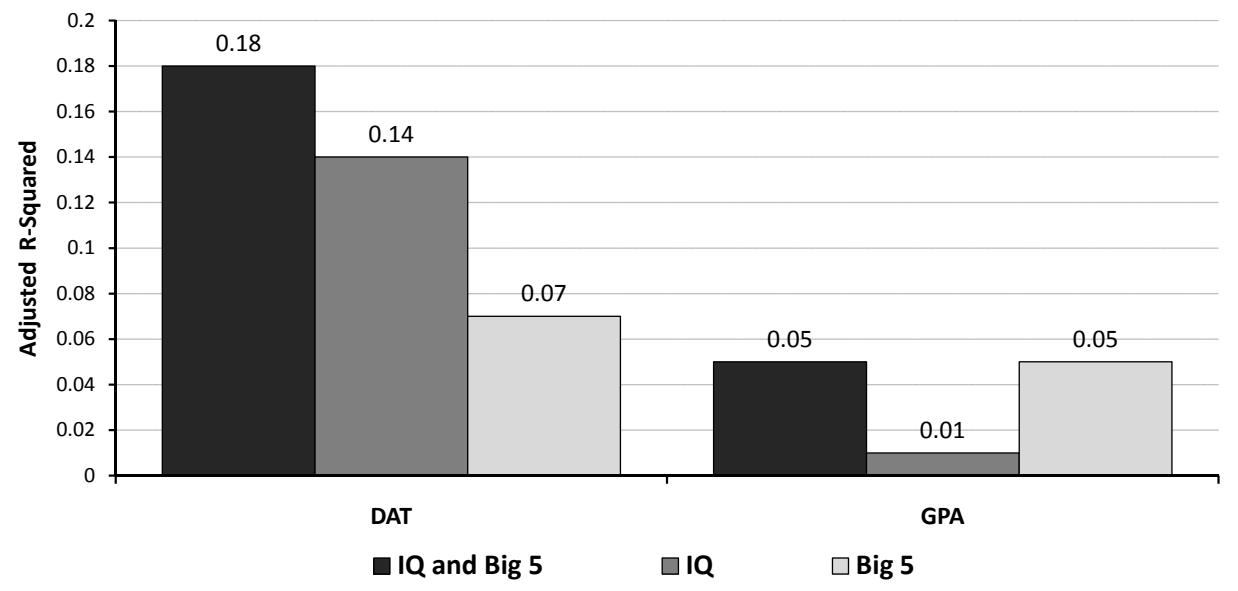

Notes: Data is from Stella Maris, a high school in the Netherlands. Students were administered part of a Raven's IQ test and personality questions based on the Big 5. DAT and GPA are from high school records.

Source: Borghans et al. (2011).

\subsection{Measures of Personality in Psychology Based on Linear Fac- tor Analysis}

Such measures account for measurement error, and identify factors that can be interpreted as traits. Cunha et al. (2010) develop nonlinear factor models (nonlinear and nonparameteric). Using these models they establish that measurement error is quantitatively important. The share of error variance for proxies of cognition, personality and investment ranges from 1\%-90\%. Not accounting for measurement error produces downward-biased estimates of self-productivity effects and perverse estimates of investment effects.

\subsection{A Definition of Personality}

I now add preferences and goals to the analysis. Preferences and goals also shape effort. They are personality traits broadly defined. Income is the return to productivity:

$$
\text { Income }=\quad \sum_{j=1}^{J} R_{j} P_{j}
$$


Preferences are defined over final consumption goods $X$, productivity $P$ and effort $e$ :

$$
U(X, P, e \mid \psi), \psi \in \Psi
$$

Agents have preferences over goods, agents may value the output of tasks in their own right and agents may value the effort devoted to tasks. The agents maximize $(3)$ with respect

$$
\underbrace{Y}_{\begin{array}{c}
\text { exogenous } \\
\text { flow of } \\
\text { income }
\end{array}}+R^{\prime} P=\underbrace{W^{\prime}}_{\begin{array}{c}
\text { prices } \\
\text { of } \\
\text { goods }
\end{array}} X
$$

\subsection{Adding Uncertainty}

Let $\mathcal{I}$ be the information possessed by an agent. " $E$ " denotes the expectation operator. The agent can be interpreted as making decisions based on

$$
E[U(X, P, e \mid \psi) \mid \mathcal{I}]
$$

\subsection{Personality Traits}

Personality traits are the components of $e, \theta$ and $\psi$ that affect behavior. We observe measured personality — behaviors generated by incentives, goals, and traits.

\subsection{Actions}

Actions are styles of behavior that affect how tasks are accomplished. They are aspects of behavior that go beyond effort. Smiling, cajoling, etc. are examples. Tasks are accomplished by taking actions. The $i^{\text {th }}$ possible

action to perform task $j$ is denoted $a_{i, j}, i \in\left\{1, \ldots, K_{j}\right\}$. Array actions in a vector $a_{j}=\left(a_{1, j}, \ldots, a_{K_{j}, j}\right) \in \mathcal{A}$. Actions may be the same or different across the tasks. The productivity of the agent in task $j$ depends on the actions taken in that task:

$$
P_{j}=\tau_{j}\left(a_{1, j}, a_{2, j}, \ldots, a_{K_{j}, j}\right) .
$$

The actions themselves depend on traits $\theta$ and "effort" $e_{i, j}$ :

$$
a_{i, j}=\nu_{i, j}\left(\theta, e_{i, j}\right)
$$


where

$$
\sum_{i=1}^{K_{j}} e_{i, j}=e_{j} \text { and } \sum_{j=1}^{J} e_{j}=\bar{e} .
$$

Actions generalize the notion of effort to a broader class of behaviors.

Let $\mathcal{M}$ be the set of actions, including actions that do not directly contribute to productivity. Let $M$ be the index set of items in $\mathcal{M}$

$$
a_{i, m}=\nu_{i, m}\left(\theta, e_{i, m}\right), m \in M, \mathcal{A} \subseteq \mathcal{M}
$$

The agent solves

$$
\max E[U(a, X, P, e \mid \psi) \mid \mathcal{I}]
$$

with respect to $X$ and $e$ given the stated constraints.

We can introduce situations indexed by $h \in \mathcal{H}$. For a person with traits $\theta$ and effort vector $e_{j}$ with action $a_{i, j}$, using the specification (7), the action function can be expanded to be dependent on situation $h$ :

$$
a_{i, j, h}=\nu_{i, j}\left(\theta, e_{i, j, h}, h\right)
$$

\subsection{A Definition of Personality}

Let $T \in \mathcal{T}$ be a vector of traits $(\theta, \psi, \bar{e})$. Personality is a response function.

$$
\text { Personality: } a=a(R, W, T, h, Y, \mathcal{I}) \text {. }
$$

The behavior that constitutes personality is defined as a pattern of actions in response to the constraints, endowments, and incentives facing agents given their goals and preferences.

Actions - not traits - constitute the data used to identify the traits. Personality psychologists use actions (e.g., "dispositions") to infer traits. Identification issues similar to those previously discussed apply to this broader set of measurements of behaviors.

\subsection{Personality as Enduring Actions}

Many personality psychologists define personality as "enduring patterns of thoughts, feelings and behaviors" that reflect tendencies of persons to respond in certain ways under certain circumstances. (See Cervone and Pervin (2009).) What are enduring patterns of actions? "Enduring actions" are the average of the $a$ 
functions for a person with a given trait vector $T=t$ over situations and efforts.

\subsection{Average Actions}

Consider task $j$ and trait vector $T=(\theta, \psi, \bar{e})$. Define the average action for information set $\mathcal{I}$ :

$$
\bar{a}_{T, j, \mathcal{I}}=\int_{\mathcal{S}_{T, \mathcal{I}}\left(h, e_{i, j}\right)} \nu_{i, j}\left(\theta, e_{i, j}, h\right) g\left(h, e_{i, j} \mid T=(\theta, \psi, \bar{e}), \mathcal{I}\right) d h d e_{i, j}
$$

where $\mathcal{S}_{T, \mathcal{I}}\left(h, e_{i, j}\right)$ is the support of $\left(h, e_{i, j}\right)$ given $T$ and $\mathcal{I}$. $g\left(h, e_{i, j} \mid T=(\theta, \psi, \bar{e}), \mathcal{I}\right)$ is the density of $\left(h, e_{i, j}\right)$ given $T=(\theta, \psi, \bar{e})$ and information set $\mathcal{I} \cdot \bar{a}_{T, j, \mathcal{I}}$ is the "enduring action" of agents across situations in task $j$ with information $\mathcal{I}$, i.e., the average personality. Only if $\nu_{i, j}$ is separable in $T$, the marginal effect of personality trait vector $\theta$ is the same in all situations.

One can define the "enduring traits" in a variety of ways, say by averaging over tasks, $j$, situations, $h$, or both. Only under separability in $T$ will one obtain the same marginal effect of $\theta$. Epstein (1979) and a subsequent literature present evidence against nonseparability but in favor of an "enduring trait" that is common across situations. He argues strongly against the extreme form of situational specificity assumed in modern behavioral economics.

\subsection{Stability and Change in Personality Traits and Preferences}

While it is commonly thought that personality traits are stable, at least in adult life, in fact traits change over the life cycle. See Figures 1316. 
Figure 13: Cumulative Mean-Level Changes in Personality Across the Life Cycle

\section{Social Dominance}

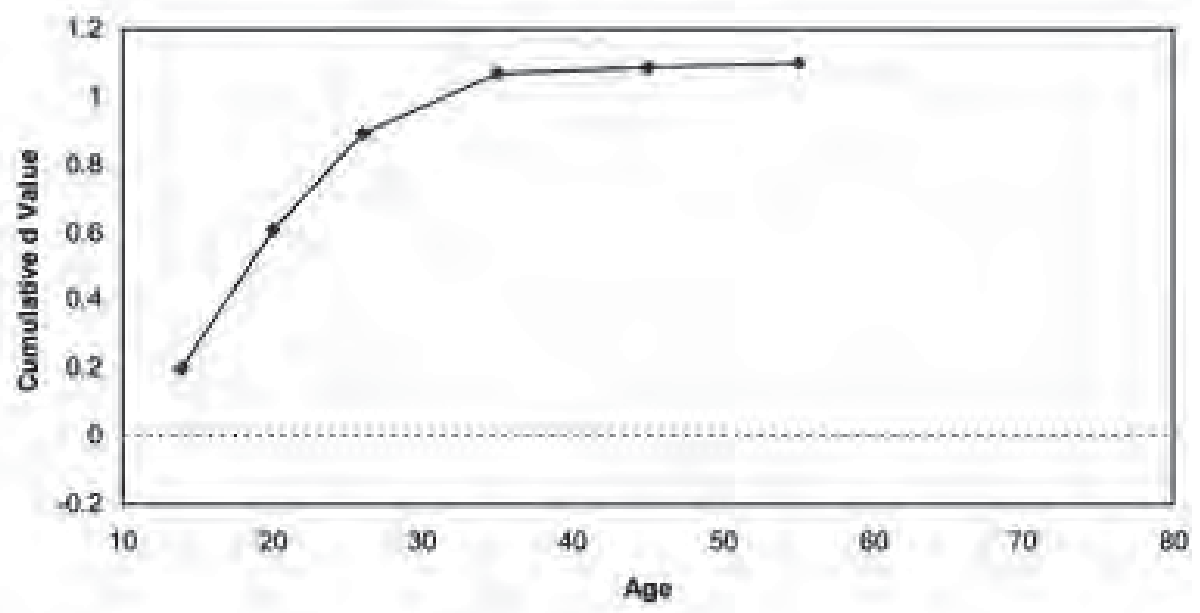

Note: Social vitality and social dominance are aspects of Big Five Extraversion. Cumulative d values represent total lifetime change in units of standard deviations ("effect sizes").

Source: Figure taken from Roberts et al. (2006) and Roberts and Mroczek (2008). Reprinted with permission of the authors.

Figure 14: Cumulative Mean-Level Changes in Personality Across the Life Cycle

\section{Agreeableness}

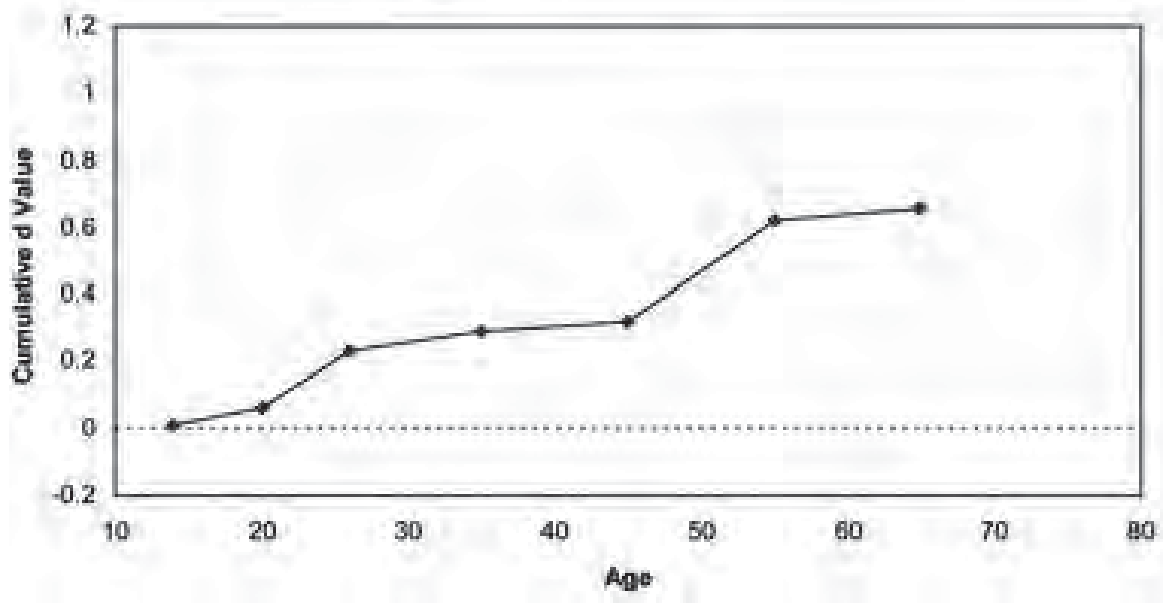

Note: Social vitality and social dominance are aspects of Big Five Extraversion. Cumulative d values represent total lifetime change in units of standard deviations ("effect sizes").

Source: Figure taken from Roberts et al. (2006) and Roberts and Mroczek (2008). Reprinted with permission of the authors. 
Figure 15: Cumulative Mean-Level Changes in Personality Across the Life Cycle

\section{Conscientiousness}

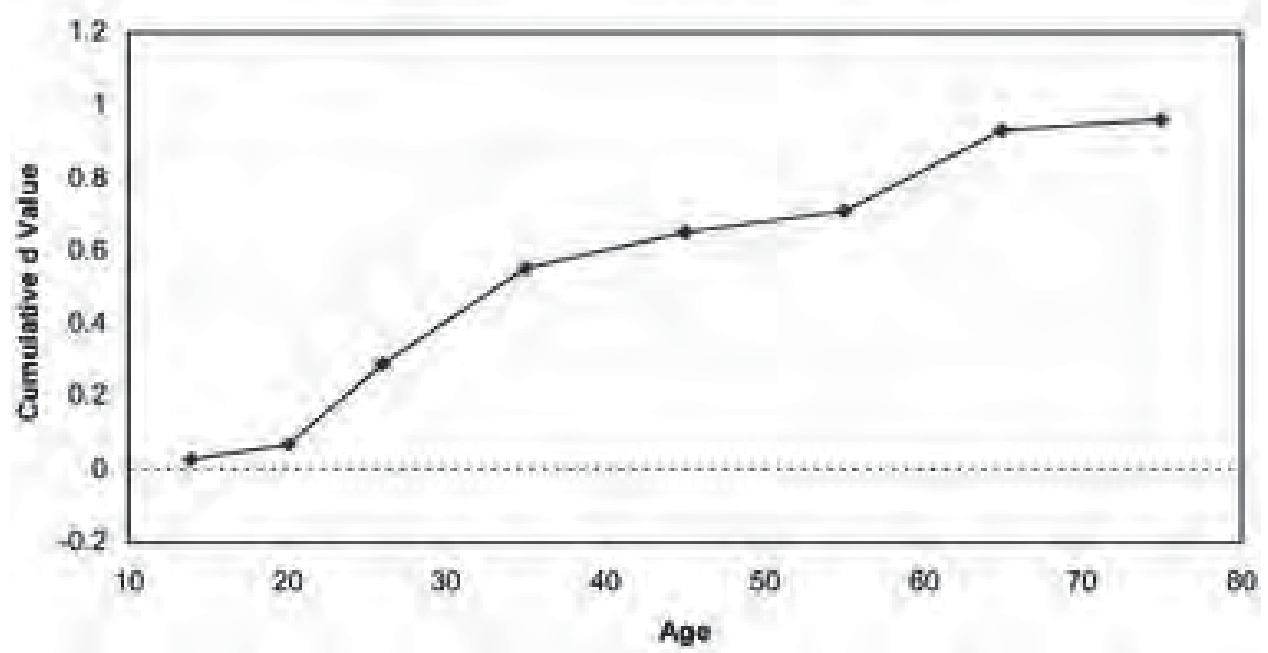

Note: Social vitality and social dominance are aspects of Big Five Extraversion. Cumulative d values represent total lifetime change in units of standard deviations ("effect sizes").

Source: Figure taken from Roberts et al. (2006) and Roberts and Mroczek (2008). Reprinted with permission of the authors.

Figure 16: Cumulative Mean-Level Changes in Personality Across the Life Cycle

\section{Emotional Stability}

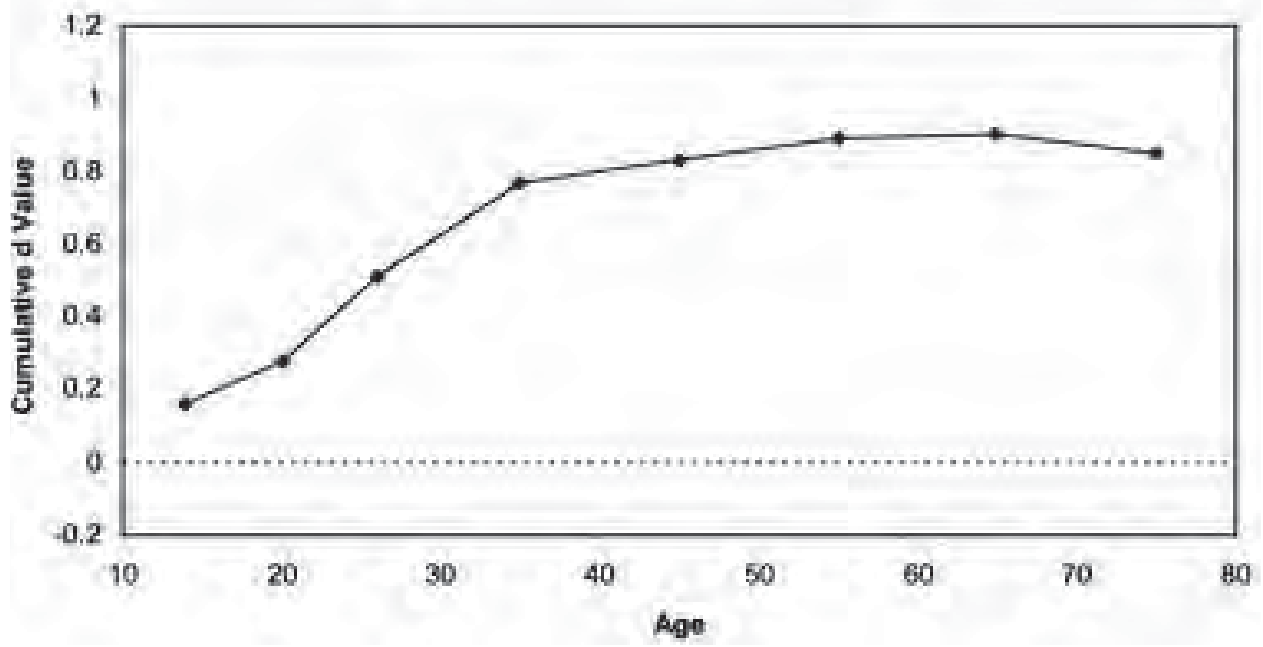

Note: Social vitality and social dominance are aspects of Big Five Extraversion. Cumulative d values represent total lifetime change in units of standard deviations ("effect sizes").

Source: Figure taken from Roberts et al. (2006) and Roberts and Mroczek (2008). Reprinted with permission of the authors. 


\subsection{Processes of Development Discussed in the Literature}

There are many hypothesized mechanisms of change. Two common processes discussed in the literature are ontogeny (programmed developmental processes common to all persons) and sociogeny (shared socialization processes). Personality also changes through external forces above and beyond common ontogenic and sociogenic processes. Such changes operate through alterations in normal biology, such as brain lesions and chemical interventions. A channel that receives a lot of attention in economics is investment: educational interventions and parental investment that affect personality throughout the lifecycle.

\subsection{Life Cycle Dynamics}

Let $T^{v}$ be traits at age $v, v \in\{1, \ldots, V\} \in \mathcal{V}$. Information $\mathcal{I}^{v}$ may be updated through various channels of learning. The technology of skill formation (Cunha and Heckman, 2007, 2009) postulates the following equation of motion:

$$
T^{v+1}=\eta^{v}(\underbrace{T^{v}}_{\text {self-productivity }}, \underbrace{I N^{v}}_{\text {investment }}, h^{v}), v=0, \ldots, V-1
$$

Functions can be nonautonomous ( $v$-dependent). Situations may change over time as a function of past actions, past situations, investment, information, and the like:

$$
h^{v+1}=\chi^{v}\left(h^{v}, I N^{v}, a^{v}\right) .
$$

Information $\mathcal{I}^{v}$ may also change over the life cycle through experimentation and learning:

$$
\mathcal{I}^{v+1}=\rho^{v}\left(\mathcal{I}^{v}, a^{v}, T^{v}, I N^{v}, h^{v}\right) .
$$

Figure 17 summarizes the dynamics of skill formation as formulated in Cunha and Heckman 2007, 2009). 


\section{Figure 17: A Life Cycle Framework for Organizing Studies and Integrating Evidence: Period Life Cycle}

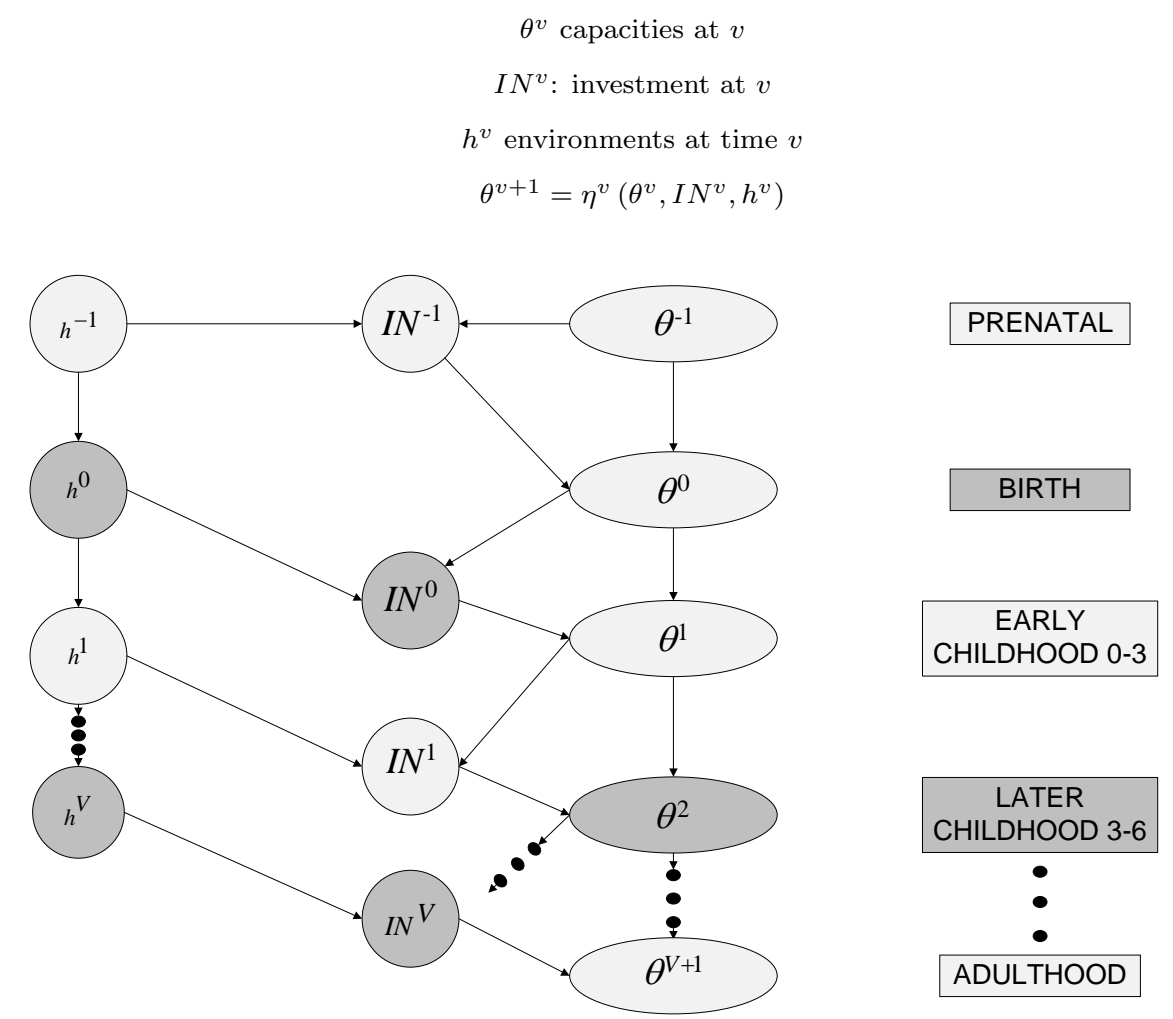

Cunha et al. (2010) estimate technology (10) using longitudinal data on the development of children with rich measures of parental investment and of child traits. Self-productivity becomes stronger as children become older, for both cognitive and noncognitive capability formation. The elasticity of substitution for cognitive inputs is smaller in the adolescent years, so that it is more difficult to compensate for the effects of adverse environments on cognitive endowments at later ages than it is at earlier ages.

This finding explains the evidence on ineffective cognitive remediation strategies for disadvantaged adolescents. Personality traits foster the development of cognition but not vice versa. Cunha et al. (2010) show that it is equally easy to substitute for deficits in personality traits at both early and late stages for socioemotional skills over the life cycle. 
Overall, $16 \%$ of the variation in educational attainment is explained by factors extracted from adolescent cognitive traits, $12 \%$ is due to factors extracted from adolescent personality (socioemotional traits), and $15 \%$ is due to factors extracted from measured parental investments.

\subsection{The Causal Effects of Schooling on Cognitive and Personality Traits}

Using the methodology of Hansen et al. (2004), it is possible to estimate the causal effect of schooling on cognitive and noncognitive measurements. See Figures 18 21. Schooling has substantial effects on both types of traits.

Figure 18: Causal Effect of Schooling on ASVAB Measures of Cognition

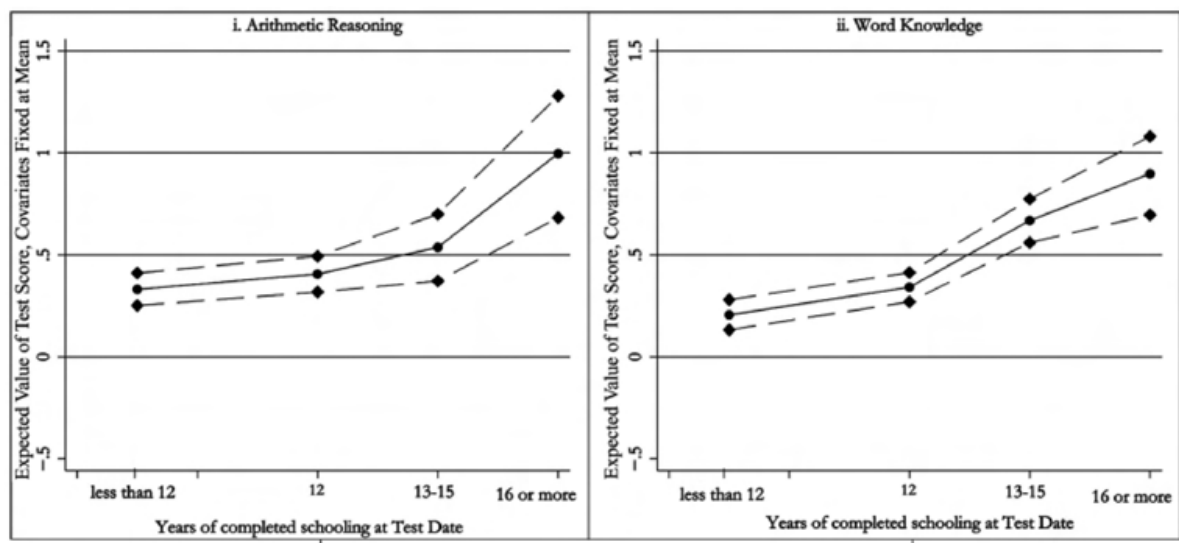

Notes: Effect of schooling on components of the ASVAB. The first four components are averaged to create male's with average ability. We standardize the test scores to have within-sample mean zero, variance one. The model is estimated using the NLSY79 sample. Solid lines depict average test scores, and dashed lines, confidence intervals.

Source: Heckman et al. (2006, Figure 4). 


\section{Figure 19: Causal Effect of Schooling on ASVAB Measures of Cognition}

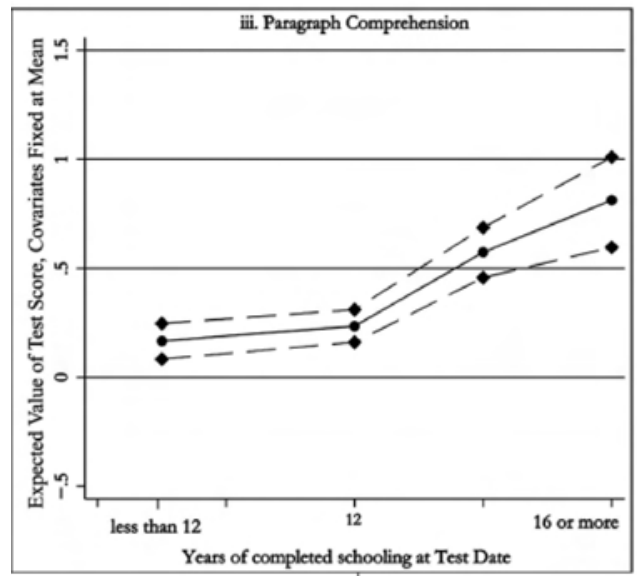

Notes: Effect of schooling on components of the ASVAB. The first four components are averaged to create male's with average ability. We standardize the test scores to have within-sample mean zero, variance one. The model is estimated using the NLSY79 sample. Solid lines depict average test scores, and dashed lines, confidence intervals.

Source: Heckman et al. (2006. Figure 4).

\section{Figure 20: Causal Effect of Schooling on ASVAB Measures of Cognition}

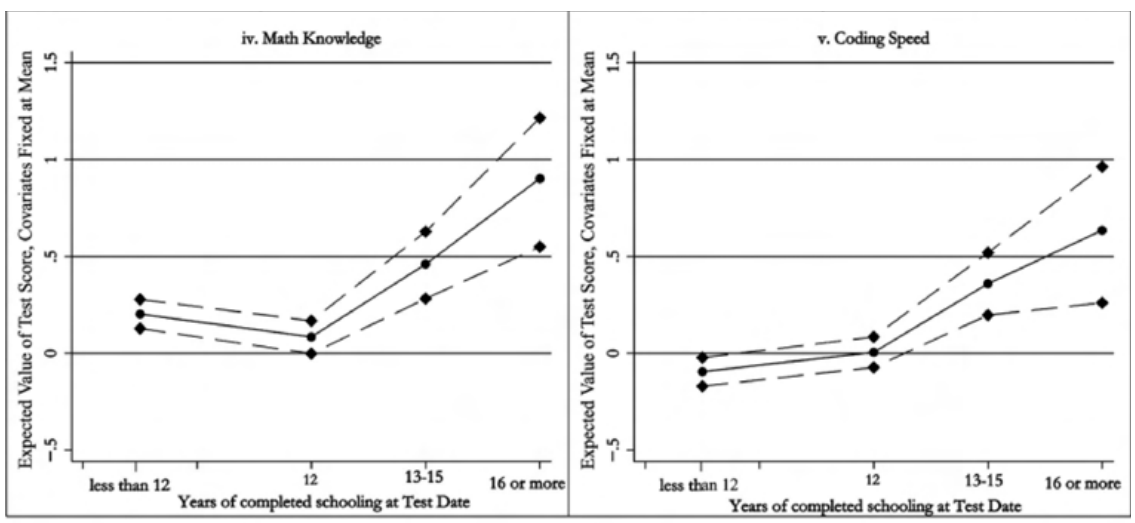

Notes: Effect of schooling on components of the ASVAB. The first four components are averaged to create male's with average ability. We standardize the test scores to have within-sample mean zero, variance one. The model is estimated using the NLSY79 sample. Solid lines depict average test scores, and dashed lines, confidence intervals.

Source: Heckman et al. (2006. Figure 4). 


\section{Figure 21: Causal Effect of Schooling on Two Measures of Personality}
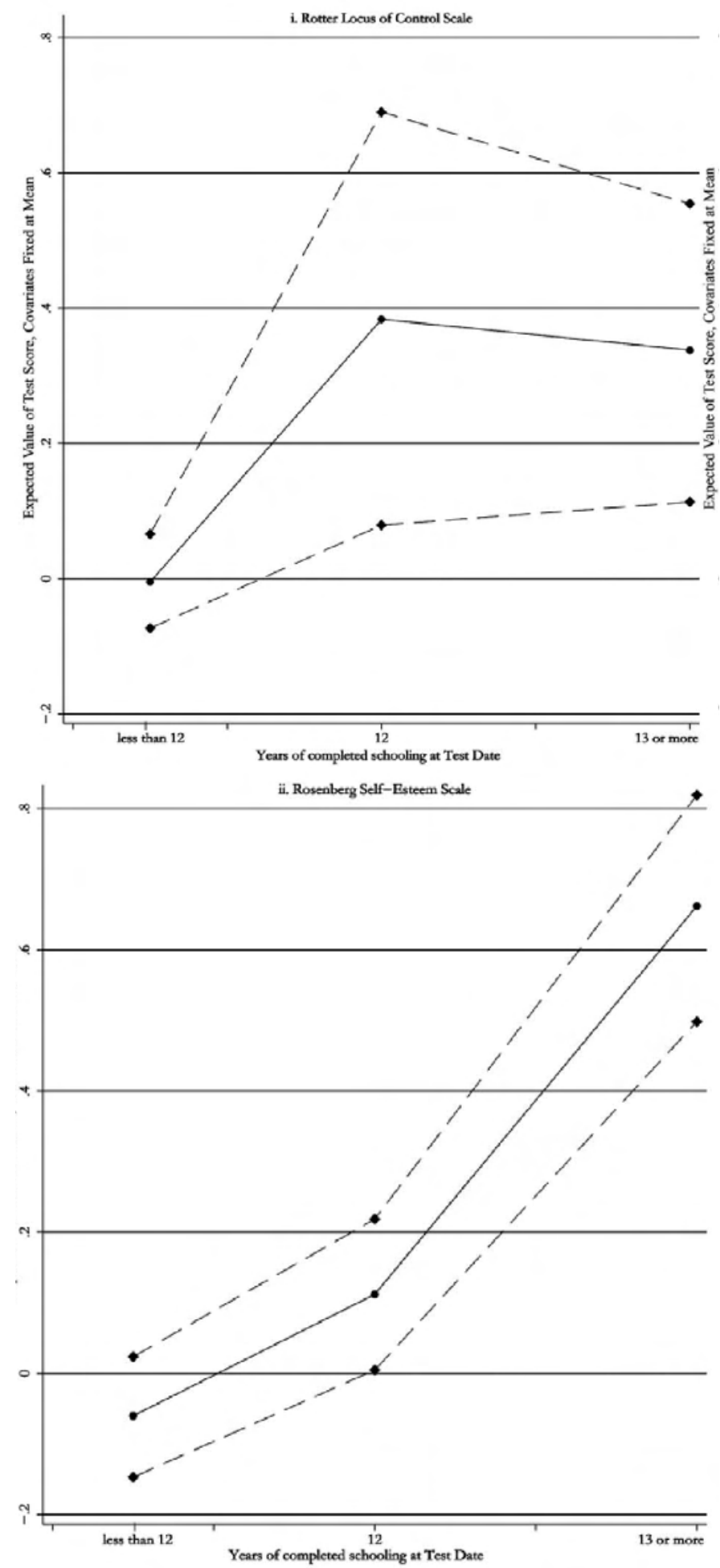

Notes: The figures show the causal effect of schooling on two measures of personality traits. We standardize the test scores to have within-sample mean zero, variance one. The model is estimated using the NLSY79 sample. Solid lines depict average test scores, and dashed lines, confidence intervals.

Source: Heckman et al. (2006 Figure 4). 


\subsection{The Evidence from Interventions}

The Perry Preschool program intervened early in the lives of disadvantaged children. It has a $7-10 \%$ rate of return per annum. (See Heckman et al., 2010.) The Perry Preschool Program did not have a lasting improvement on cognitive ability, but it did improve important later-life outcomes through changes in personality (Heckman et al. 2011).

Figure 22: Perry Preschool Program: IQ, by Age and Treatment Group

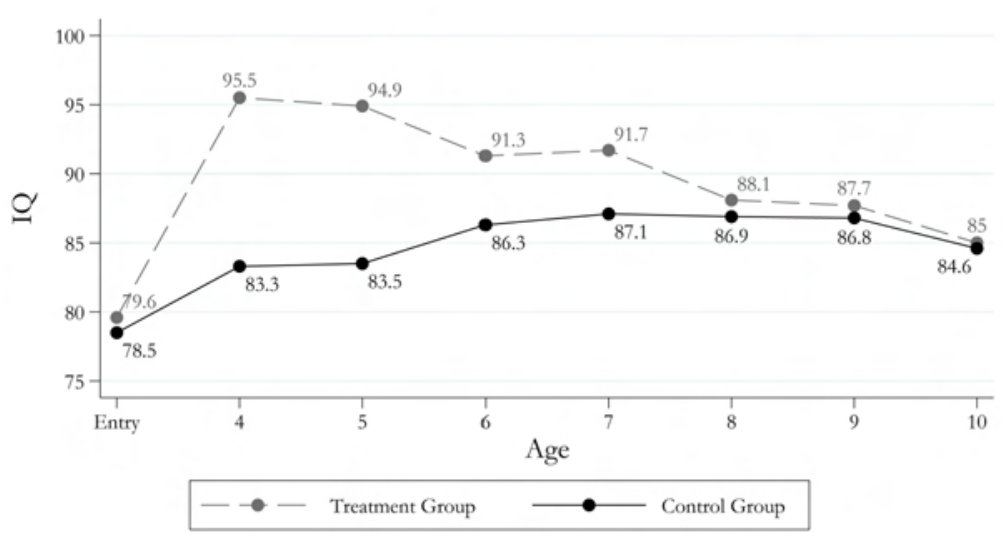

Notes: IQ measured on the Stanford-Binet Intelligence Scale (Terman and Merrill 1960). Test was administered at program entry and each of the ages indicated.

Source: Cunha et al. (2006) and Heckman and Masterov (2007) based on data provided by the High Scope Foundation.

The Perry Preschool Program worked primarily through socioemotional channels. It raised scores on achievement tests but not IQ tests. As previously noted, socioemotional factors and cognitive factors both explain performance on achievement tests (Duckworth, 2007; Borghans et al., 2008, Borghans et al., 2009).

\subsection{Personality and Preference Parameters}

Measures of personality predict a wide range of life outcomes that economists study. Personality psychologists define traits as relatively stable, person-specific determinants of behavior. Preferences are the natural counterpart of these traits in economics. However, the exact link between personality and preferences is unclear. Table 3 shows one possible correspondence between conventional economic preference parameters and personality measures. 


\section{Table 3: Standard Preference Parameters and Conceptually Similar Measures}

\section{in the Psychology Literature}

\begin{tabular}{ll}
\hline \hline Preference parameter & Personality measures \\
\hline Time preference & $\begin{array}{l}\text { Conscientiousness } \\
\text { Self-control } \\
\text { Affective mindfulness } \\
\text { Consideration of future consequences } \\
\text { Elaboration of consequences } \\
\text { Time preference }\end{array}$ \\
& $\begin{array}{l}\text { Impulsive sensation seeking } \\
\text { Balloon Analogue Risk Task }\end{array}$ \\
Risk aversion & Achievement Striving \\
Leisure Preference & Endurance \\
& Industriousness \\
Social preference & Warmth \\
& Gregariousness \\
& Trust \\
Altruism \\
Tender-mindedness \\
Hostility \\
\end{tabular}

An empirical literature is emerging that attempts to make this correspondence. See Table 4

\section{Table 4: Empirical Studies of the Links Between Preferences and Traits}

\begin{tabular}{|c|c|c|}
\hline Preferences & Personality measure & Empirical study \\
\hline \multirow[t]{2}{*}{ Time Preference } & $\begin{array}{l}\text { Conscientiousness, Self-control, } \\
\text { Affective mindfulness, Elaboration of } \\
\text { consequences, Consideration of future } \\
\text { consequences. }\end{array}$ & Daly, Delaney and Harmon [2009] \\
\hline & $\begin{array}{l}\text { Extraversion } \\
\text { Time Preference }\end{array}$ & Dohmen, Falk, Huffman et al. [2010] \\
\hline \multirow[t]{4}{*}{ Risk Aversion } & Sensation Seeking & $\begin{array}{l}\text { Zuckerman [1994], Eckel and } \\
\text { Grossman [2002] }\end{array}$ \\
\hline & Openness & Dohmen, Falk, Huffman et al. [2010] \\
\hline & Neuroticism, ambition, Agreeableness & $\begin{array}{l}\text { Borghans, Golsteyn, Heckman et al. } \\
\text { [2009] }\end{array}$ \\
\hline & Balloon Analogue Risk Task & Lejuez, Aklin, Zvolensky et al. [2003] \\
\hline \multicolumn{3}{|l|}{ Social Preferences } \\
\hline Altruism & Neuroticism, Agreeableness & $\begin{array}{l}\text { Ashton, Paunonen, Helmes et al. } \\
\text { [1998],Osiński [2009] , Bekkers [2006 }\end{array}$ \\
\hline Reciprocity & $\begin{array}{l}\text { Neuroticism, Agreeableness, } \\
\text { Conscientiousness }\end{array}$ & Dohmen, Falk, Huffman et al. [2008] \\
\hline Trust & $\begin{array}{l}\text { Neuroticism, Agreeableness, Openness, } \\
\text { Conscientiousness }\end{array}$ & Dohmen, Falk, Huffman et al. [2008] \\
\hline
\end{tabular}




\subsection{Summary and Conclusions}

What can economists take from and contribute to personality psychology? What do we learn from personality psychology? Personality traits predict many behaviors sometimes with the same strength as conventional cognitive traits. Personality psychology considers a wider array of actions than are usually considered by economists. It enlarges the economist's way to describe and model the world. Cognition is one aspect of personality broadly defined.

Personality traits are not set in stone. They change over the life cycle. They are a possible avenue for intervention and policy.

Personality psychologists lack precise models. Economics provides a framework for recasting the field. More precise models reveal basic identification problems that plague measurement in psychology. Such analyses show that, at an empirical level, "cognitive" and "noncognitive" traits are not easily separated.

Personality psychologists typically present correlations - not causal relationships. Many contemporaneously measured relationships suffer from the problem of reverse causality. Econometric tools can be used to define and estimate causal mechanisms and to understand the causes of effects. Psychological measures have substantial measurement error. Econometric tools account for measurement error, and doing so makes a difference. Economists can formulate and estimate mechanisms of investment - how traits can be changed for the better.

There are major challenges in linking the traits of psychology with the preferences, constraints and expectation mechanisms of economics. Developing rigorous methods for analyzing causal relationships in both fields remains to be done. Developing a common language and framework to promote interdisciplinary exchange is required. There is a danger in assuming that basic questions of content and identification have been answered by psychologists at the level required for rigorous economic analysis. 


\section{References}

Ackerman, P. L. and E. D. Heggestad (1997). Intelligence, personality, and interests: Evidence for overlapping traits. Psychological Bulletin 121, 219-245.

Almlund, M., A. Duckworth, J. J. Heckman, and T. Kautz (2011). Personality psychology and economics. In E. A. Hanushek, S. Machin, and L. Wößmann (Eds.), Handbook of the Economics of Education, Volume 4. Amsterdam: Elsevier. Forthcoming.

Ashton, M. C., S. V. Paunonen, E. Helmes, and D. N. Jackson (1998). Kin altruism, reciprocal altruism, and the Big Five personality factors. Evolution and Human Behavior 19(1), 243-255.

Barrick, M. R. and M. K. Mount (1991). The Big Five personality dimensions and job performance: A meta-analysis. Personnel Psychology 44(1), 1-26.

Bekkers, R. (2006). Traditional and health-related philanthropy: The role of resources and personality. Social Psychology Quarterly 69(4), 349-366.

Binet, A. and T. Simon (1916). The development of intelligence in children (The Binet-Simon Scale). Psychological Science. Baltimore, MD: Williams \& Wilkins Co.

Borghans, L., A. L. Duckworth, J. J. Heckman, and B. ter Weel (2008, Fall). The economics and psychology of personality traits. Journal of Human Resources 43(4), 972-1059.

Borghans, L., B. H. Golsteyn, J. J. Heckman, and H. Meijers (2009, April). Gender differences in risk aversion and ambiguity aversion. Journal of the European Economic Association 7(2-3), 649-658.

Borghans, L., B. H. H. Golsteyn, J. J. Heckman, and J. E. Humphries (2011). IQ, achievement, and personality. Unpublished manuscript, University of Maastricht and University of Chicago (revised from the 2009 version).

Borghans, L., H. Meijers, and B. ter Weel (2008, January). The role of noncognitive skills in explaining cognitive test scores. Economic Inquiry 46(1), 2-12.

Carroll, J. B. (1993). Human Cognitive Abilities: A Survey of Factor-Analytic Studies. New York: Cambridge University Press.

Cervone, D. and L. A. Pervin (2009). Personality: Theory and Research (11th ed.). Hoboken: John Wiley and Sons, Inc. 
Costa, P. T. and R. R. McCrae (1992). Revised NEO Personality Inventory (NEO PI-R) and the NEO Five-Factor Inventory (NEO-FFI) professional manual. Odessa, FL: Psychological Assessment Resources.

Cunha, F. and J. J. Heckman (2007, May). The technology of skill formation. American Economic Review $97(2), 31-47$.

Cunha, F. and J. J. Heckman (2009, April). The economics and psychology of inequality and human development. Journal of the European Economic Association 7(2-3), 320-364. Presented as the Marshall Lecture, European Economics Association, Milan, Italy, August 29, 2008.

Cunha, F., J. J. Heckman, L. J. Lochner, and D. V. Masterov (2006). Interpreting the evidence on life cycle skill formation. In E. A. Hanushek and F. Welch (Eds.), Handbook of the Economics of Education, Chapter 12, pp. 697-812. Amsterdam: North-Holland.

Cunha, F., J. J. Heckman, and S. M. Schennach (2010, May). Estimating the technology of cognitive and noncognitive skill formation. Econometrica 78(3), 883-931.

Daly, M., L. Delaney, and C. P. Harmon (2009). Psychological and biological foundations of time preferences. Journal of the European Economic Association 7(2-3), 659-669.

Dohmen, T., A. Falk, D. Huffman, and U. Sunde (2008). Representative trust and reciprocity: prevalence and determinants. Economic Inquiry 46(1), 84-90.

Dohmen, T., A. Falk, D. Huffman, and U. Sunde (2010). Are risk aversion and impatience related to cognitive ability? American Economic Review $100(3), 1238-1260$.

Duckworth, A. L. (2007). Unpublished dataset. University of Pennsylvania, Department of Psychology.

Eckel, C. C. and P. J. Grossman (2002). Sex differences and statistical stereotyping in attitudes toward financial risk. Evolution and Human Behavior 23(4), 281-295.

Epstein, S. (1979). The stability of behavior: I. on predicting most of the people much of the time. Journal of Personality and Social Psychology 37(7), 1097-1126.

Goldberg, L. R. (1993). The structure of phenotypic personality traits. American Psychologist 48(1), 26-34.

Gough, H. G. and A. B. Heilbrun (1983). The Adjective Check List Manual. Palo Alto, CA: Consulting Psychologists Press.

Hansen, K. T., J. J. Heckman, and K. J. Mullen (2004, July-August). The effect of schooling and ability on achievement test scores. Journal of Econometrics 121(1-2), 39-98. 
Heckman, J. J. and B. E. Honoré (1990, September). The empirical content of the Roy model. Econometrica 58(5), 1121-1149.

Heckman, J. J., J. E. Humphries, S. Urzúa, and G. Veramendi (2011). The effects of educational choices on labor market, health, and social outcomes. Unpublished manuscript, University of Chicago, Department of Economics.

Heckman, J. J., L. Malofeeva, R. Pinto, and P. A. Savelyev (2011). Understanding the mechanisms through which an influential early childhood program boosted adult outcomes. Unpublished manuscript, University of Chicago, Department of Economics (first draft, 2008). Under revision, American Economic Review.

Heckman, J. J. and D. V. Masterov (2007). The productivity argument for investing in young children. Review of Agricultural Economics 29(3), 446-493.

Heckman, J. J., S. H. Moon, R. Pinto, P. A. Savelyev, and A. Q. Yavitz (2010, February). The rate of return to the HighScope Perry Preschool Program. Journal of Public Economics 94(1-2), 114-128.

Heckman, J. J. and G. L. Sedlacek (1985, December). Heterogeneity, aggregation, and market wage functions: An empirical model of self-selection in the labor market. Journal of Political Economy 93(6), 1077-1125.

Heckman, J. J., J. Stixrud, and S. Urzua (2006, July). The effects of cognitive and noncognitive abilities on labor market outcomes and social behavior. Journal of Labor Economics 24(3), 411-482.

John, O. P. and S. Srivastava (1999). The big five trait taxonomy: History, measurement and theoretical perspectives. In L. A. Pervin and O. P. John (Eds.), Handbook of Personality: Theory and Research, Chapter 4, pp. 102-138. New York: The Guilford Press.

Lejuez, C. W., W. M. Aklin, M. J. Zvolensky, and C. M. Pedulla (2003). Evaluation of the Balloon Analogue Risk Task (BART) as a predictor of adolescent real-world risk-taking behaviours. Journal of Adolescence 26(4), 475-479.

Mischel, W. (1968). Personality and Assessment. New York: Wiley.

Osinski, J. (2009). Kin altruism, reciprocal altruism and social discounting. Personality and Individual Differences 47(4), 374-378.

Poropat, A. E. (2009). A meta-analysis of the five-factor model of personality and academic performance. Psychological Bulletin 135(2), 322-338.

Roberts, B. W. (2006). Personality development and organizational behavior. In B. Staw (Ed.), Research on Organizational Behavior, Volume 27, Chapter 1, pp. 1-41. Oxford, UK: Elsevier Science/JAI Press. 
Roberts, B. W. (2009). Back to the future: Personality and assessment and personality development. Journal of Research in Personality 43(2), 137-145.

Roberts, B. W., N. R. Kuncel, R. L. Shiner, A. Caspi, and L. R. Goldberg (2007, December). The power of personality: The comparative validity of personality traits, socioeconomic status, and cognitive ability for predicting important life outcomes. Perspectives in Psychological Science 2(4), 313-345.

Roberts, B. W. and D. Mroczek (2008). Personality trait change in adulthood. Current Directions in Psychological Science 17(1), 31-35.

Roberts, B. W., K. E. Walton, and W. Viechtbauer (2006). Patterns of mean-level change in personality traits across the life course: A meta-analysis of longitudinal studies. Psychological Bulletin 132(1), 1-25.

Schmidt, F. L. and J. Hunter (2004). General mental ability in the world of work: Occupational attainment and job performance. Journal of Personality and Social Psychology 86(1), 162-173.

Terman, L. M. and M. A. Merrill (1960). Stanford-Binet Intelligence Scale: Manual for the Third Revision Form L-M. Boston: Houghton Mifflin.

Thaler, R. H. (2008, July). A short course in behavioral economics. Edge Master Class, Sonoma, CA, July $25-27,2008$.

Zuckerman, M. (1994). Behavioral Expressions and Biosocial Bases of Sensation Seeking. New York: Cambridge University Press. 